subsequent formation of a loam $\left(F^{\prime}\right)$. Another period of slight aggradation with a temperate fauna $(G)$ was followed by advance of an English glacier $(H)$, when the land was depressed some 150 feet.

The sequence of the first interglacial was repeated, but during a shorter second interglacial. Uplift was followed by erosion (I), valleys being excavated, generally along previously established drainage lines though some deflections occurred. Aggradation $(J)$ was continued into a temperate period. A colder oscillation $(K)$ was followed by temperate conditions, and deposition of a loam $(L)$. A period of slight erosion $(M)$ cut into the loam, and the Upper Boulder Clay was then deposited as a skin over the greater part of the Breckland, though not in the hills to the south.

This boulder clay and its associated gravels form an Upper Terrace dissected by an erosion phase $(O)$ which cut out the present radial drainage of the Breckland. A Middle terrace was formed of well bedded gravels $(P)$. Towards the upper part a cold fauna is succeeded by a bed $(Q)$ showing the effects of sludging under severe cold conditions. A period of erosion and aggradation forms a late Low Terrace $(R)$.

Because of its general lithological character and physiographic configuration the Lower Boulder Clay (the Great Chalky Boulder Clay of West Norfolk and Suffolk) is equated with the Norwich Brickearth. The Middle Boulder Clay is equated with the Great Chalky Boulder Clay (the Great Eastern Drift) of East Norfolk and Suffolk. The Upper Boulder Clay is equated with the 'Upper Chalky Boulder Clay and Little Eastern Drift'. A more widespread correlation is not possible here, but will appear in the full memoir, which, it is hoped, will be published later this year.

At several horizons palæolithic industries have been discovered. The Acheulean is divisible into Lower a and $b$, Middle $a$ and $b$, Upper $a$ and $b$, and Final. The Clactonian can similarly be subdivided, into Lower $a$ and $b$, Middle $a$ and $b$, and Upper $a$ and $b$. In general, it may be said that :

The Lower Acheul occurs during the early part of the Lower-Middle Interglacial prior to phase $(E)$ and is characterized by free flaking, no controlled secondary work, no fine retouch, thickness, cortex remains, irregular outline and dominant pyriform shapes.

The Middle Acheul occurs during the later part of the Lower-Middle Interglacial and is characterized by the presence of much controlled secondary working, some retouch (more in Middle $b$ ), and linguate and ovate forms dominant. (In southern England the pseudo-Micoquian is dominant in Middle b.)

The Upper Acheul appears in the Middle-Upper Interglacial and is characterized by much controlled secondary working, fine retouch including controlled step retouch, thinness, no cortex, very fine and regular outlines (twisted forms common), small foliates, pointed ovates and straight-sided pyriform types dominant.

The Final Acheul appears in the post-Upper Boulder Clay aggradation gravels with the same general characters as the Upper Acheul, somewhat finer if anything, but the 'proto-celt' and the triangular forms appear.

The Lower Clacton occurs in the same period as Lower Acheul, with massive flakes, generally much cortex remaining, no controlled secondary retouch, no specifically prepared forms, and the cores coarsely biconvex and serrate, with no flat-bottomed forms.

The Middle Clacton occurs in the same period as the Middle Acheul and has thinner flakes, cortex wholly removed, controlled secondary working, some retouch, specifically prepared forms, points and suchlike, proto-Levallois and Levallois cores, biconvex, serrate and flat-bottomed.

The Upper Clacton occurs in the same period as the Upper Acheul. Apparently the Upper Acheul has absorbed some northern Upper Clacton* elements and the only dominantly Clacton industry is of southern faciest, direct descendant of a Middle Clacton $b$ of the Thames. The flakes are equally sideand end-types from biconvex and flat-bottomed cores, and of specific shapes. There are no pseudo- or proto-Levallois flakes or cores. The flakes are strong with median ridges instead of flake scars. There is no secondary working, but finely developed scaling retouch. Outlines are regular.

Faceted, possibly Levallois, flakes are occasionally found but no industry has so far been unearthed.

On broad palæontological and stratigraphical grounds, the Pleistocene is divided into Lower, Middle and Upper. This division corresponds to three cycles of deposition, the first being less marked than the others. Both Middle and Upper begin with extensive land movement. The Lower is so named because of the Villafranchian and late Villafranchian character of the fauna.

" "Tayacian" stem of the Clacton.

t "Mousterian" stem of the Clacton.

\title{
British Empire Telegraph Communications
}

$\mathrm{D}$ URING the last ten years very rapid progress has been made in both telegraph and radio communication throughout the British Empire. In a paper by K. L. Wood recently read to the Institution of Electrical Engineers, the engineering aspect of the whole of this world-wide communication is considered. A short history of progress in cable telegraphy is given, but full explanations are given of novel technical methods. Methods of operating radio are also described, and reference is made to the effects of varying cosmic conditions on radio signals.
September 29, 1929, was a notable date in world communication, as on that date all the telegraph communications of the British Empire were, by Act of Parliament, placed in the hands of a single operating company. At the same time an Imperial Communications Advisory Committee was set up, the members of which were nominated by the British and Dominion Governments. A long list is given of the main companies taken over by the operating company. In addition, the ship and aireraft services were taken over as well as various small radio 
circuits. In many parts of the world, the cable systems have been reorganized. The terminals of certain radio circuits in South Africa, India, Canada, Egypt and Australia are operated by local companies.

The Post Office also maintains a broadcast telegraph service on long and short wave-lengths. Radiotelephony in the United Kingdom is con. trolled and operated by the G.P.O., but the overseas terminals in the Dominions are controlled by the local companies or by the operating company. The operating company also handles abroad the shore end of various ship services, some of which are fitted with direction-finding apparatus. At Nairobi, Bermuda and Bahrain, Adcock direction-finding stations for air services are in operation. There are radio-phototelegraph services with New York, Buenos Aires, Melbourne and Tokio ; also land telephony in Cyprus and Peru, and broadcasting in Kenya. The present telegraph system comprises 155,090 nautical miles of submarine cable, 125 wireless circuits, and 161 overseas branches. The tables given show that nearly all the Empire routes from the United Kingdom are served both by cable and by wireless. London stands out clearly as the focal point of the whole system.

During certain periods of the day, much of the traffic between distant parts of the Empire passes through London. For example, South Africa-India traffic may travel via the Cape Town-London beam and the London-Bombay, or via the cable chains over the same route. Many alternative routes to Australia are given. The choice as between wireless and cable is primarily dependent on the senders' instructions; but the particular route is regulated in part by the out-payments that have to be made on the various routes. These depend very largely on the time of traffic flow, and this, again, is largely dependent upon the business times in various parts of the world. During the night on a route which is served both by wireless and by cable, the cable circuit may carry the bulk of the traffic, since the majority of the cable chain stations may have to be kept fully manual to serve other routes; methods have now been devised which largely overcome the effects of 'fading' and 'atmospherics'. Verdan working, while largely eliminating fades and atmospheries, fails when both these factors are present at the same time. Considerable experimental work is still being carried out, but only with limited success.

The author also considers the effect of cosmic conditions on wireless telegraph circuits, and explains how in practice large use is made of the effects of the solar cycle when predicting future conditions. The optimum wave-lengths of transmission for any given route are dependent upon the season and the time of the day and-this is an important factor-the degree of solar activity, which is found to follow approximately an $11 \frac{1}{2}$ years' cycle. The last sunspot maximum period was during 1928-29, and the minimum period during 1933-34. The years following the latter period have been accompanied by a marked increase in activity, which on a half-yearly basis exhibited a well-defined peak for January-June 1937. Records for the past hundred years reveal that, whilst the average length of cycle is $11 \cdot 4$ years, the change from minimum to maximum activity occurred over an average period of only 4.5 years; a study of wireless data for the year 1938 indicates that it is not improbable that the year 1937 may prove to have been the maximum peak of the present cycle. Unlike long-wave transmission, it is found that increased solar activity, with its increase in ionization, enhances the utility of the shorter wave-lengths.

At certain times and seasons, the attenuation of wireless signals is so low over both the major and minor ares of the great circle embracing the two terminals that signals may arrive both by the forward and the backward route, and even encircle the globe some two or three times. Diagrams are given showing the reception at the P.O. station at Bridgwater of two consecutive dots transmitted from Cape Town together with a sequence of three 'echoes' of the main transmission, as the result of the rays encircling the globe three times.

\section{The Gorge Dam, Hong Kong}

\begin{abstract}
THE problem of providing adequate water storage to meet the needs of the population of Hong Kong is a peculiarly difficult one by reason of the relatively large population living in a small mountainous area in which the rainfall is confined to the monsoon period of about six months. Although provided with twelve reservoirs with a gross capacity of 3,000 million gallons, there were only seven years since 1921 during which an unrestricted supply of water could be given. Faced with the necessity of obtaining further supplies, the director of public works, Mr. R. M. Henderson, came to the conclusion that the best solution lay in constructing a reservoir which should impound the waters of the Shing Mun - a river situated in an area on the mainland, leased from the Chinese Government in 1898 for a period of ninety-nine years and known as the 'leased territory'.
\end{abstract}

The scheme, as finally developed, provided for the construction of a reservoir having a capacity equal to the combined capacities of the existing reservoirs, thus doubling the provision for the Colony. To give effect to this plan it was necessary to build several dams and, of these, the largest-the Gorge Dampresents both in its design and in its construction several features of especial interest. These were described in a paper read before the Institution of Civil Engineers by W. J. E. Binnie and H. J.F. Gourley on January 24.

The design selected as most suitable for the purpose and place was based on two principal considerations-oconomy in construction and the elimination of eracks such as would allow of the penetration of water and might arise from earth tremors or from volumetric changes due to the thermal phenomena exhibited in large masses of setting concrete.

The dam has a height of $275 \mathrm{ft}$. above the streambed and its length at the top is $690 \mathrm{ft}$. Its main structure, the 'thrust block', is not the actual dam but, in conjunction with the 'rock-fill' and the 'sand wedge', acts as a support for the 'diaphragm' or screen which forms the barrier to the water 